\title{
Strategies for Teaching ESP Vocabulary in Nigerian Universities
}

Chinelo Nwokolo, $\mathrm{PhD}^{*}$

Directorate of General Studies Federal University of Petroleum Resources Effurun, Delta State, Nigeria

DOI: $10.36348 /$ sjhss.2020.v05i11.005 $\quad$ | Received: 18.10 .2020 | Accepted: 03.11.2020 | Published: 26.11 .2020

*Corresponding author: Chinelo Nwokolo, $\mathrm{PhD}$

\section{Abstract}

Despite the status of English as dominant language in Nigeria, a lot is still required to enhance its effective teaching and learning. Being a second language in Nigeria, English is confronted with difficulties faced by students, teachers, and researchers of the language. This raises a need for professional based English teaching. It is on this note that this paper reviewed different strategies developed by different scholars in the teaching of ESP vocabulary under the framework of Communicative Approach to language teaching. The paper observed that the teaching ESP vocabulary in Nigerian context requires a combination of methodologies and concluded that lecturers of ESP should utilize methodologies that encourage interactive use of the target vocabulary. The paper recommended that individual lecturers should experiment with various strategies and choose any combinations they find most suitable for both their learners and the teaching circumstances.

Keywords: Vocabulary, ESP teaching, Nigerian universities, teaching strategies, and EFL.

Copyright () 2020 The Author(s): This is an open-access article distributed under the terms of the Creative Commons Attribution 4.0 International License (CC BY-NC 4.0) which permits unrestricted use, distribution, and reproduction in any medium for non-commercial use provided the original author and source are credited.

\section{INTRODUCTION}

English for Specific Purposes (ESP) has become an essential branch in English language teaching. Professionals increasingly demand ESP programs to match the development in their own field, since learning a foreign language is closely related to vocabulary knowledge. Both teachers and learners of English as foreign language (EFL) have various issues to contend with because learning vocabulary is not only complex but also multidimensional [1].

Vocabulary knowledge is an essential consideration especially for learners of English for specific purpose, such as undergraduates and workers who seek professional development. Some writers have maintained that words allow the learners to extend their understanding of the world around them and to access completely new worlds [2, 3]. They argued that vocabulary knowledge affects both reading performance and students' ability to participate effectively in both social and academic classroom interactions. However, for all students to benefit maximally from vocabulary instruction, the instruction must be conducted according to their strength and specific needs. In view of the above, Richards [4] noted three important trends in language teaching: the traditional approaches (up to late 1960s), and a move toward classic communicative teaching (1970s to 1990s), and current communicative language teaching (CLT, 1990s to the present) respectively, which shifted L2 researchers' focus from traditional lesson formats towards using innovative tasks such as pair work activities, role plays and group work activities. CLT demystifies the view of the teacher as a dictator in the learning process and recreates a new image of the teacher as leader, facilitator, and leader.

These trends led to the development of the ESP movement in 1970s-1980s. Hutchinson and Waters [5] asserted its practical domain was driven by needs of people who needed English for specific purposes such as higher education (HE), professional development, and business objectives. Specific courses preparing learners for their workplace with objectives are distinct from other course plans [6]. A major proportion of all information in science and engineering throughout the world is in English and this implies the significance of ESP in language teaching programs [7, 8, 3]. Different views on ESP course plans, vocabulary teaching programs are required to enlarge learners' potential in extracting meaning and to develop the knowledge of the jargon of the genre.

Parisa and Saba [3] posed the essential question on the choice of effective teaching procedure that can enhance vocabulary learning of ESP learners. 
Parisa and Saba [3] shared in Watts-Taffe and Truscott's [9] suggestion that word learning is supported by the provision of rich explanation to elaborate and contextualize word meanings, using nonverbal cues such as facial expressions, gestures, illustrations, and other visuals.

Students generally acquire new vocabulary through new words in their textbooks and new words they encounter in their classroom. A limited knowledge of English vocabulary may hinder the performance of learners in at least four ways: the social relationships with other students, participation in academic learning routines, comprehension as a part of reading instruction, and comprehension as a part of content area instruction [2].

By taking into account the importance of ESP vocabulary and the problems learners may encounter through their lack of knowledge in workplace settings, successful vocabulary programs are needed to expand the learners' level of knowledge [3]. It is therefore expedient to stress the need for strategies that will enhance effective teaching and learning of ESP vocabulary. The purpose of this study is therefore to identify from previous studies the strategies for teaching ESP vocabulary.

\section{The Communicative Approach to Language Teaching}

The Communicative Approach (CA) is one of the most prominent pedagogies in contemporary English language teaching (ELT). Commonly known as CA and sometimes referred to as CLT, the pedagogy proposes that learners achieve more by participating in meaningful communication in the course of learning. Lesson are broken down into tasks and activities in which the teacher leads the learners in the CA pedagogy. Learners are guided to engage in various classroom interaction patterns such as:

- Student-to-student

- Student-to-teacher

- Teacher-students

- Whole-class discussion

The teacher provides guidance in the process but endeavours not to dominate it. Both teaching and learning are learner-centred in this methodology and teachers allot more student talking time (STT) than teacher talking time (TTT). Learners could benefit immensely from the CA ESP teaching of vocabulary through activities such a matching. Okoh [10] encouraged ESP teachers to adopt a communicative approach for the following reason:

For the ESP teacher, employing newer approaches to language teaching, especially those usually referred to as communicative, constitutes a positive measure. The changing face of language teaching means that for the teacher, learner-centredness becomes the centre-piece of classroom methodology. Of course, the learner is no longer conceived of as a passive character or "as some soft, soggy, sleepy sponge to absorb, and soak up knowledge from some classroom dictator called the teacher" [10].

It may be argued with regards to Okoh's view above that no teaching methodology is exclusively superior to others. However, CA lends itself to be more easily combined with other methodologies such as Task-Based Learning (TBL), Present, Practice, Produce (PPP), Community Language Learning (CLL), and Lexical Approach than some other pedagogy. It is also suitable for the needs of innovation, practice, recycling, and matching that have become hallmarks of the teaching of vocabulary in ESP.

\section{LITERATURE REVIEW}

Hutchinson and Waters [5] indicated that all ESP programs were necessitated by the demands of the electronic age, a revolution in linguistics, and the focus on learners. Learner needs for revolutionary linguistics led to the emergence of ESP programs. For Tamar [8], the vast expansion in scientific, technical, and economic activities increased the demand for learning ESP courses. In comparison with the traditional linguists, revolutionary linguists focus on how languages were used in real situations. The effect of ESP development exerted increased pressure on language teaching [3].

Ewer [11] recognized that traditionally, English teachers receive training in literature and language but they tend to claim English for general purposes as their specialist discipline and display a hostile attitude to other specialist areas such as English for science and technology. Widdowson [12] presented a dual view of learner needs. One was goal-oriented definitions of needs and related to terminal behaviour. The other was process-oriented definitions of needs and related to transitional behaviour, (i.e., the means of learning). Swales [13] indicated that most studies of lexis and ESP were centered on language, not pedagogy.

Halliday, McIntosh, and Strevens [14] noted that the ESP course design addresses learner needs, such as English for civil servants, and for others. In Nababan's [15] view, specific areas and learner types are the most important elements for consideration in designing ESP teaching programs. ESP teaching materials should be based on a syllabus that covers all of the learner needs in their present studies and future professions. According to the suggestions by Munby [16] and Parisa and Saba [3], learner needs should be the first criterion for ESP course design and ESP materials should be derived from the syllabus specific communicative needs of learners. Nababan [15] opined that a vocabulary component forms the core of numerous ESP programs. English is an alphabetic language and therefore, establishing a connection 
between spelling and pronunciation can greatly influence ESP vocabulary recognition and reading ability [3]. Word decoding and recognition ability are vital factors that improve ESP reading comprehension and speed. The knowledge of basic affixes, roots, suffixes, and word formation help learners decode ESP vocabulary.

Decomposing an unfamiliar word into its structural components and inferring its meaning from the components is called structural analysis. Some writers $[17,19,18,20]$ have mentioned that learning affixes can successfully teach students ESP vocabulary through structural analysis. This was illustrated by Ahaotu [21] with the following diagram:

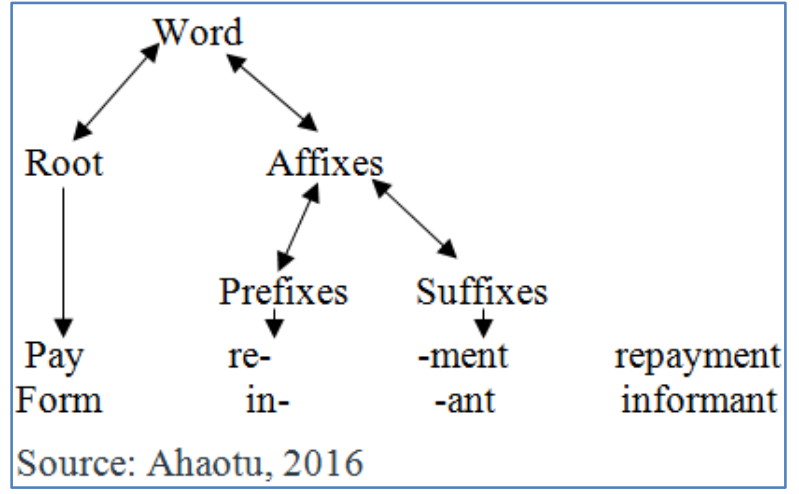

Fig-1: Decomposing words

By becoming familiar with a few roots, affixes, and suffixes, students can determine the meaning of many words, even if they are unfamiliar.

In addition, teaching the word formation of ESP vocabulary can help learners memorize and recognize it in an effective manner. Word decoding instruction results in improving learners' ability to infer word meaning. Dudley-Evans and John [22] distinguished two types of ESP vocabulary: general vocabulary that has higher frequency or that has specific meaning in a particular field. They also asserted that rather than teach technical vocabulary, ESP teachers should ensure that learners understood technical vocabulary that function as carrier content for an exercise. This paper attempted to identify the possible strategies that could be adopted by ESP teachers in the teaching of ESP vocabulary in Nigeria.

Vocabulary learning involves choices that teachers could make from a wide range of strategies; several steps to learn; and it requires knowledge and benefit from training to increase the efficiency of vocabulary learning and use [23]. Therefore some of the possible vocabulary learning strategies for teaching ESP vocabulary are the following: synonyms/antonyms, learning words by categories, by topic, by word families and also vocabulary cards. Nation [17] emphasizes the importance of prior knowledge of the topic and that real world knowledge can play a vital part in guessing, especially when it provides the schema or the background knowledge for readers. Another strategy used by the learners to find word meaning of the unknown is the monolingual dictionary.

In general monolingual dictionaries contain much more information about each word than bilingual dictionaries [17]. Takac [21] noted that vocabulary learning strategies are particular strategies used for learning vocabulary in either general English or ESP. Learning vocabulary for speaking and writing, as productive skills, requires different strategies from learning vocabulary for listening and reading, as perceptive skills [24]. In the views of Parisa and Saba [3], vocabulary learning is not easy, and so, applying strategies becomes crucial for success. Vocabulary teaching/learning strategies can be direct (mostly applied for productive vocabulary skills) and indirect (mostly used for receptive vocabulary skills). Morphological analysis of word structure is effective for both direct (used in class) and indirect (used in independent work) strategies of vocabulary learning. Vocabulary resourcefulness enhances reading comprehension and listening comprehension strategies.

\section{Learning ESP Vocabulary}

Learning ESP vocabulary in Nigerian higher education institutions (HEIs) can enhance overall language learning, proficiency, and professional competence. ESP offers a wide range of courses to Nigerian students ranging from faculties such as, Business Administration, Social Sciences, Law, Engineering, Natural Sciences, Environmental Sciences, Health Sciences, Arts and Education. All Students of Nigerian HEIs take ESP courses. In the ESP courses, students face difficulties while learning new English words. It is challenging to learn ESP words because many of them are low frequency words that do not occur often in usage. Without words that aid the expression of wider ranges of meanings, effective L2 communication will be difficult to achieve $[21,25]$.

In a related development, Schmitt [1] emphasized that the goal of vocabulary learning is to transfer lexical information from short-term memory to long-term memory; since lexical information is first stored in the short term memory during the period of manipulating language and later transferred to permanent memory. Schmitt's view may be summarized as follows:

- $\quad$ Short-term memory is also called working memory. Working memory is linked to human consciousness and its characteristic is that it holds a limited amount of information for a limited amount of time. The role of the working memory in this case is to extract visuals, for example, that are relevant for ongoing comprehension but the capacity of the working memory is always limited.

- Long-term memory serves as the storage area of 
information. The amount of information that people hold there is not known but the information can be stored for a long period of time. However, instead of words being represented alphabetically, concepts are represented according to their associations to one another. An example is the word "blue" and what usually comes to mind is the sky which is closely associated with blue or "red" usually associated with love.

According to Driscol [26] episodic memory refers to specific events such as how one learned a thing, whereas semantic memory refers to all the general information stored in memory and could be remembered without recourse to how the information was learned. Learners can more easily remember concrete words such as: peach, house, and horse if they appear on a list than abstract words such as freedom and injustice because the verbal system represents the meaning of the words, but the imagination system represents images of the words. Driscol [26] noted that concrete words are remembered better because they offer these two memories available at recall, as opposed to only one for abstract words.

Xhaferi [27], opined that ESP courses are designed to cater for students' needs based on their field of study. The design goal is to enhance their proficiency and help them to get ready to cope with everyday situations and deal with professionals in many fields such as: engineering, medicine, education, IT, etc. There are many training sessions organized by international experts whose goal is to train local teachers to teach these courses successfully.

In order to develop an ability to learn new vocabulary, for both general English and technical vocabulary in learning ESP, the students should become aware of the significance of language learning strategies and be trained to use them appropriately. The teachers put a lot of effort toward helping them to learn vocabulary related to their field of study.

Xhaferi [27] observed that reading contributes to vocabulary growth in L1. Learners with advanced reading skills and who read extensively would achieve vocabulary development without direct instruction. These incidental gains in vocabulary should not cause teachers to either ignore or rely solely on incidental acquisition. Rather, they should enhance the effectiveness of incidental independent learning of vocabulary with vocabulary logs, word walls and other techniques. According to Nation [17], the vocabulary of written texts is presented in four different categories:

1. High-Frequency words including many content words, e.g., government, forests, production, adoption, represent, boundary;

2. Academic words include many words that are common in various kinds of academic texts, e.g., policy, phase, sustained
3. Technical words are closely related to the topic and subject area (words from the field of agriculture) in the text, e.g., indigenous, beech, podocarp, regeneration, rimu, timber;

4. Low-Frequency words include words like pastoral, aired, perpetuity, and zone.

\section{Teaching ESP Vocabulary}

Dudley-Evans and St John [22] are of the opinion that ESP teachers should not teach technical vocabulary but should check if the learners understood technical vocabulary that appears as carrier content for an exercise. The use of lexical chunks helps students write and communicate better and they should be able to distinguish high-frequency and low-frequency lexical items. It is also widely believed that language fluency and accuracy is achieved largely by retrieving and combining ready-made chunks of language [28]. Most of the students taking ESP identify it with specific terminology related to their field of study. There are degrees of technicality depending on how restricted a word is to a particular area [17]. Nation claimed that technical vocabulary is a type of specialized vocabulary and its occurrence is affected by factors that influence the use of all vocabulary. Language teachers should prepare their learners to deal with the large numbers of technical words that occur in specialized texts [17]. Kavaliauskienë and Janulevièienë [28] suggested that the lexical approach is very useful in teaching ESP.

Xhaferi [27] stated that in ESP, words are perceived as more complex than general words and students should spend more time learning them. This is probably due to the fact that collocations are very frequent in ESP and combining them correctly requires more effort. He buttressed that there are specific types of collocations in ESP which cause students' errors due to a lack of translational equivalence between the students' first language and the second language. ESP teachers should aim at assisting learners to familiarize with ESP collocations, and the tendency of words to go together [29]. Morgan and Rinvolucri [30] believed that the new words are not learned mechanically, but associatively.

Sysoyev [31] pointed out that Vygotsky introduced the notion of a mediator: someone that helps students to achieve more than they can achieve by themselves. In ESP, that role falls on the teacher, who ought to assist students through the stages of their needs. The challenge for teachers is to systematize the vocabulary in English. Developments in technology will help us in collecting and analyzing current and specialized corpora (ESP), and both spoken and academic English in order to develop better descriptions of lexical phrases and collocations [32]. Language learning strategies can support all aspects of language learning therefore the teachers should encourage students to use different strategies to learn ESP and general English words. 
Many strategies are non-observable but students and teachers can discuss them or design questionnaires to find more information and make more use of it. Researchers and scholars should put more effort into designing tools that could provide more information on the usage of non-observable strategies.

\section{Suggested Strategies for Teaching ESP Vocabulary in Nigeria}

The teaching of ESP vocabulary in Nigeria may benefit from the established status of English as L2 and dominant language in the country. Whether ESP is taught in the academic or the professional development context, ESP learners in Nigeria come from a background of widespread use of English at various levels of communication outside the classroom. ESP lecturers may take advantage of this background in designing course content and in selecting course materials. Unlike in foreign language (FL) contexts, Nigeria's L2 context provides greater opportunities of recycling and practicing the use of the target vocabulary. Teachers may explore any or a combination of vocabulary teaching and learning strategies (knowing word parts, knowing the origin of words, using context clues, learning word families, playing word games, using flash cards and knowing learning lexical relationships) as explicated in Ahaotu [18] for teaching vocabulary in Nigeria. Based on Nation's [17] view, vocabulary learning strategies should involve choice (since there are several strategies to choose from) and be complex (since there are several steps to learn). It requires knowledge and benefits from training; increases the efficiency of vocabulary learning and vocabulary use. In applying Ahaotu's [18] strategies, teachers could assist the learners in using the following strategies:

1. Knowing word parts: Teachers could assist learners by demonstrating how knowledge of the meanings of word parts could help them in decomposing words and figuring out the meanings, such as in figure 1 above. Learning the root form "loqu" (or "loqui", "eloqui') may assist the learners in decomposing words such as: loquacious, eloquent, grandiloquent, breviloquent, soliloquy, colloquial, colloquy, and colloquist.

2. Knowing the origin of words: Teachers could assist learners in developing ESP vocabulary by teaching them the etymology of words and helping them to learn word meaning through stories. Words such as: Achilles heel, Adonis, bandwagon, brainiac, herculean, Lilliputian, Machiavellian, Midas touch, narcissism, odyssey, quixotic, Rambo, Sisyphean, Spartan, spoonerism, stoic, narcissism, tuxedo and utopia, etc. can easily be learnt through their origins.

3. Using context clues: Teachers could integrate this strategy into reading comprehension tasks to demonstrate how learners could utilize context clues in deciphering the meaning of unfamiliar words. This strategy also enhances comprehension of texts involving polysyllabic words.

4. Playing word games: Apart from serving as a form of entertainment, word-based games such as (analogy, scrabble and lexical relationships [which accounts for derivational inflections of words) may be utilized in teaching ESP vocabulary. The teacher is, however, required to choose appropriate levels of register for the learners' needs.

5. Using flash cards: ESP teachers may use flash cards as memory aids that enhance learning of target vocabulary. The target words are written on sheets of paper cut to a rectangular shape of approximately the size of credit cards while lexical details of word spelling, meaning, and sound are written on both sides. Learners can then take a small number of the cards with them for the purpose of reminding themselves of the details as often as possible until the information is internalized. Particularly difficult words and concepts can easily be learnt through this strategy.

6. Knowing learning lexical relationships: ESP teachers may also consolidate vocabulary learning by helping learners to link learned words with others through lexical relationships. Words may be related to one another as synonyms, antonyms, hyponyms, homophones, homonyms, etc. Target vocabulary could be pre-arranged in lexical relationships to enhance learning and practical usage.

In addition to these strategies, vocabulary teaching in ESP in Nigeria should be divided into two stages - presenting and practicing. The practical and useful activities recommended are:

\section{Matching exercises}

- match the word to its definition or to its equivalent in learners' mother tongue;

- match the term with opposites/synonyms;

- match the term to the picture/symbol/diagram/abbreviation;

- match collocations (two terms that go together).

2. Categorization of words (putting the lexical items into different categories), multiple choice (learners are proposed to choose the correct word), completion tasks, often known as gap-filling exercises, and the creation tasks (the students should be encouraged to use the new words sentences or a story, in writing, speaking or in both forms).

\section{CONCLUSION}

This paper attempted to identify the possible strategies that could be adopted in Nigeria by ESP teachers in the teaching of ESP vocabulary in the country. The study has established from the foregoing, the important place of ESP vocabulary teaching in foreign language learning and agrees that “... every academic failure is, to a great extent, a linguistic 
failure" [33]. ESP vocabulary learning constitutes the greater bulk of target categories for academic and professional development in L2. It is pertinent that lecturers themselves determine the pedagogy or the combinations of pedagogies that work best in their classrooms. Also, greater attention in teaching English for professional communication should be paid to teaching specialized vocabulary and structures of expression peculiar to the discipline. To create a productive learning process, vocabulary should be taught in well-defined contexts from the point of view of Communicative Approach. The teaching material should be carefully chosen by a language teacher in line with the context and purpose for such teaching. The teacher's role is to facilitate learning process by means of creating favourable learning conditions, introducing specific vocabulary/language structures, and leading the learners in practicing how to use the target words.

\section{RECOMMENDATIONS}

Based on the conclusion above, the paper makes the following recommendations:

1. ESP lecturers ought to experiment with different strategies in the teaching of ESP vocabulary in Nigeria and choose any combination that proves to be effective in their classrooms. This process would ensure that learner needs are more effectively catered for in the specific situations.

2. The students should be made aware of the importance of vocabulary learning strategies and be trained to use them appropriately. Following such strategies will help students to understand subject matter and the purpose of ESP would be achieved.

\section{REFERENCES}

1. Schmitt, N. (2000). Vocabulary in language teaching. Cambridge: Cambridge University Press.

2. Blachowicz, C. L., \& Fisher, P. (2005). Integrated Vocabulary Instruction. Learning Point Associates.

3. Parisa, R., \& Saba, Z. (2012). ESP vocabulary instruction: Investigating the effect of using a game oriented teaching method for learners of English for Nursing. Journal of Language Teaching and Research, 3(6): 1258-1266.

4. Richards, K. (2003). Qualitative inquiry in TESOL. Springer.

5. Hutchinson, T., \& Waters, A. (1999). How communicative is ESP? ELT Journal, 38(2), 108113.

6. Dovey, T. (2006). What purposes, specifically? Rethinking purposes and specificity in the context of the "New Vocationalism". English for Specific Purposes, 25(4), 387-402.

7. Zengin, B., Erdogan, A. R., \& Akalin, S. (2007). Acquisition of Latin roots with implications for EAP. Journal of Language and Linguistics Studies, 3(1), 11-31.

8. Tamar, T. (2016). Vocabulary learning strategies of English for Specific Purposes students at
Agricultural University of Georgia. Journal of Education in Black Sea Region, 2(1).

9. Watts-Taffe, S., \& Truscott, D. M. (2000). Focus on research: Using what we know about language and literacy development. Language Arts, 77(3), 258.

10. Okoh, N. (2016). An Overview of Communication Skills in English: Introduction to Language Skills. In Studies in communication skills in English. Umera-Okeke, N. P., \& Nutsukpo, M. F. (Eds). Port Harcourt: Oceanprint Communications Ltd. 215.

11. Krashen, S., \& Terrell, T. (1983). The Natural Approach: Language Acquisition in the Classroom. Englewood Cliffs, NJ: Alemany Press.

12. Widdowson, H. G. (1983). Talking Shop: On Literature and ELT. ELT journal, 37(1), 30-35.

13. Swales, J. D., Abramovici, A., Beck, F., Bing, R. F., Loudon, M., \& Thurston, H. (1983). Arterial wall renin. Journal of hypertension. Supplement: official journal of the International Society of Hypertension, 1(1), 17-22.

14. Mcintosh, A., \& Strevens, P. (1964). The linguistic sciences and language teaching. London: Longman's.

15. Utari, S., \& Nababan, S. (1993). Metodologi Pengajaran Bahasa. Gramedia Pustaka Utama, Jakarta, PT.

16. Munby, J. (1978). 1978: Communicative syllabus design. Cambridge: Cambridge University Press.

17. Nation, I. S. P. (2001). Learning vocabulary in another language. Cambridge: Cambridge University Press.

18. Ahaotu, J. O. (2016). Strategies for vocabulary development. In Studies in communication skills in English. Umera-Okeke, N. P., \& Nutsukpo, M. F. (eds). Port Harcourt: Oceanprint Communications Ltd. 353-372.

19. Hsueh, M. C., Tsai, T. K., \& Iyer, R. K. (1997). Fault injection techniques and tools. Computer, 30(4), 75-82.

20. Okiche, I., \& Kontein-Trinya, R. S. (2018). Explication of the morphemic layer of meaning. In Ngwoke, O. O., Out, O. O., Anurudu, S. M., Ahaotu, J. O., \& Igbifa, E. E. (Eds). Ripples of genius: Essays in honour of Seiyifa Koroye. Port Harcourt: Pearl Publishers International Ltd. 444453.

21. Ahaotu, J. O., \& Ndimele, O.-m. (2008). Improving speech fluency through vocabulary development. Kiabara 14 (II). $195-201$.

22. Dudley-Evans, T., \& John, M. (1998). Developments in English for Specific Purposes. UK: Cambridge University Press.

23. Newton, J. \& Nation, I. S. P. (1997). Vocabulary and teaching. In Coady, J. \& Huckin, T. (Eds.). Second language vocabulary acquisition. Cambridge: Cambridge University Press. 238-254.

24. Laufer, B., \& Paribakht, T. S. (1998). The relationship between passive and active 
vocabularies: Effects of languagelearning context. Language learning, 48(3), 365-391.

25. McCarthy, M. (1990). Vocabulary. Oxford: Oxford University Press.

26. Driscol, P. M. (2005). Psychology of Learning for Instruction. (3rd ed). USA: Pearson Education, Inc.

27. Xhaferi, B. (2010). Teaching and learning ESP vocabulary. In Revista de Lenguas Para Fines Específicos.

28. Kavaliauskienë, G. \& Janulevièienë, V. (2000). Using the Lexical Approach for the acquisition of ESP vocabulary: To translate or not to translate in teaching ESP? 'Network', A Journal for English Language Teacher Education, 3(3),

29. Lewis, M. (1993). The lexical approach: The state of ELT and the way forward. Hove, England: Language Teaching Publications.

30. Morgan, J., \& Rinvolucri, M. (2004). Vocabulary. (2nd ed). Oxford: Oxford University Press.
31. Sysoyev, P. V. (2000). Developing English for Specific Purposes course using a learner-centred approach: A Russian experience. The Internet TESL Journal, VI. Retrieved from the web on November 9, 2007: http://iteslj.org/Techniques/ Sysoyev-ESP.html.

32. Sökmen, A. (1997). Current trends in teaching second language vocabulary. In Schmitt, N. \& McCarthy, M. (Eds.). Vocabulary: Description, acquisition and pedagogy. Cambridge: Cambridge University Press, 237-257

33. Okoh, N. (2018). Managing change in ESP: A pedagogical perspective from Port Harcourt. In Ngwoke, O. O., Out, O. O., Anurudu, S. M., Ahaotu, J. O., \& Igbifa, E. E. (Eds). Ripples of genius: Essays in honour of Seiyifa Koroye. Port Harcourt: Pearl Publishers International Ltd. 371383. 